\title{
DEVOLVER NADA AO NADA: A EXPERIÊNCIA POÉTICA DE BRASA ENGANOSA
}

Alexandre André NODARI ${ }^{1}$

É difícil dar conta de um livro de poemas tão múltiplo (mas talvez não polifônico), como é brasa enganosa, de Guilherme Gontijo Flores. Oscilando - por vezes sem passagem - entre o humor ao grave, atravessado por referências díspares (de Tomás de Aquino a Belchior), repleto de experimentações as mais diversas, com especial atenção à disposição tipográfica e visual, incluindo alguns "Daguerreótipos de cão" (especialmente emocionantes para aqueles que perderam recentemente um companheiro canino de tantos anos, fato que redobra - torciona para intensificar - a experiência de ausência presente (saudade) que Gontijo capta na fotografia: "a foto não encontra o que no cão / ainda permanece cão encontra / outra forma que sobre o pelo adere / sem encontrar a pele o cheiro o corpo / que forma o cão que ali não mais se encontra"), e tendo quase em seu centro um labirinto em que a leitura se perde, para poder refazer seu caminho, ou multiplicar seus caminhos, labirinto que parece replicar o índice e as páginas de abertura de seções, que servem tanto como um roteiro quanto para referenciar o abismo da perda - e tudo pontilhado pelo sexo, como não poderia deixar de ser em um discurso mais próximo ao mito que ao logos -, o livro ainda é parte de uma tetralogia in progress (que inclui o poema-

${ }^{1}$ Universidade Federal de Santa Catarina- UFSC - CEP 88062-253 - Florianópolis - SC - Brasil - alexandre.nodari@gmail.com 
site Tróiades: http://www.troiades.com.br/), cujo título - Todos os nomes que talvez tivéssemos - por si só renderia uma resenha.

Todavia, a meu ver, há algo que, se não une, atravessa a maioria dos poemas, uma tessitura por vezes mais explícita, por vezes mais implícita: aquilo que Paulo Rónai (em referência a construções de Guimarães Rosa, tais como "impoder, acronologia, antipesquisas, indestruir, inimaginar") chamou de "antinomia metafísica": "abstrações opostas a fenômenos percebíveis pelos sentidos", que, contudo, aludem "a uma nova modalidade de ser ou de agir, a manifestações positivas do que não é". Desde a prece "Aos deuses dos mortos", que abre brasa enganosa, parece que estamos nesse cenário contra-ontológico, ou de ontologia invertida: um espaço que, como lemos no poema, não é nem isso nem aquilo, "mas em toda parte / jaz". Nele, aprendemos que "o desamar sim / se desaprende" (em uma dupla negação ao título do poema: "Não se aprende a amar" - e uma tripla a Drummond?); e talvez a tarefa da poesia - ao menos segundo Gontijo - consista nesse aprendizado, ou seja, o de tirar consistência do real para acessar uma dimensão negativa: "em miríades do desvario / as santas desessências canto / triunidade interior / imparte intoda". Por todo o livro, nos defrontamos com construções desse tipo: "desmapa", "pintura invista", "sombra de quadro impintado"; um dos poemas se chama rosianamente "Inconto". E dentre elas, a que mais aparece, em variadas formas (geralmente como verbo), é a "despétala". Mas o que exatamente seria uma despétala, ainda mais se Gontijo define a própria "flor" de que ela (des)parte (de que ela é negação) como uma "coisa sem nome / que sequer perdura"? A resposta talvez seja que a antinomia metafísica, o descascamento contínuo do ser que a poesia de Gontijo apresenta, acabe chegando não ao puro nada, mas, ao contrário, a uma zona de não-coincidência do ser consigo mesmo, em que ele difere de si, já é outro: a postura de "ser contra mim", postura "que germina de mim" também "rabisca / no rabo do olho / o invisível in / efável in / ventável / muito além de mim". As dessências cantadas pelo antipoeta levam, assim, a um "outrosser / 
outraver de mim". No núcleo da negação, o desfazimento, o nada (ou "quase" - para usar um termo importante do livro - nada) aparece como um processo de diferimento, que remete a outra linguagem e a outro tempo:

(nada se encontra nada resta para além de uma palavra feito undo noutra língua noutrora que não esta)

Por isso, podemos dizer da brasa enganosa, que "do sem sentido é que ela incita / uma poética / a partir do nada". E, nesse sentido, a tessitura de nada que vai envolvendo os poemas do livro revela estar o tempo todo formando um "casulo", outra figura constante no livro (junto a análogas como a "manta", a "segunda pele", ou a "hera enlaçando (...) quase parasita", a "larva da seda envolta no próprio laço", etc.), indicando o momento intersticial de transformação, morte $e$ vida, pois: a morte aparece como a "mais-matéria desta vida / que rouba ou dá significado" a este "desmundo descoberto em desmedida". É ela que permite ao ser "Parir-se", ou seja, fazer a experiência da alteridade, da transformação, ser diferente de si: "sou mesmo o asfalto do passeio onde passo \& que também me atravessa".

E aqui a dimensão política do livro diante de nossa "Paisagem digesta", em que "é tudo / imensamente / luz / 24h", em que a negatividade se perdeu por completo: "onde encontrar o traço / sem o negro necessário / da penumbra? onde / a matéria negra a noite / primordial - filha do / caos mãe do / s i l ê n c i o?" A poesia de Gontijo se apresenta, desse modo, como uma tentativa de devolver noite à noite, devolver escuridão a um mundo totalmente iluminado, que, justamente por isso, parece incapaz de produzir qualquer sentido; advoga assim pela re-invenção do "mistério", por "mitos que iluminem / tanto céu", que ajudem a entender 
a "reviravolta na máquina / do mundo", por um "mote // que transmute / o meu silêncio / in / significante / ou segurança de saber / sobre as futuras / catástrofes climáticas prefixas / pelo fim / do calendário". 0 silêncio, a negatividade, desse modo, transformase imediatamente (renasce) em um grito de revolta diante de um cenário em que não há "nenhum grito na noite":

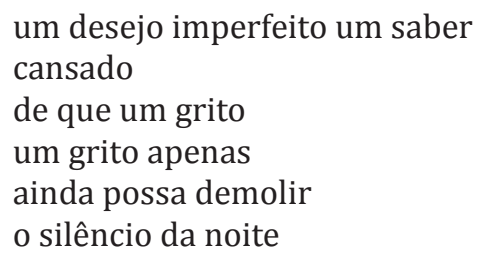

Em sua clássica formulação, Aristóteles afirmou que o poeta e o filósofo, o amante de mitos e o amante do saber, partem ambos do espanto, embora sigam caminhos distintos. Hoje, o caminho do conhecimento, do saber, parece não ter fim, não acabar, como se fosse um rio que tivesse na "foz / seu único destino". Que o progresso não termine nunca, mesmo ao custo do mundo - e que ninguém se espante com isso: talvez toda poesia comece aí, no espanto diante da ausência da finitude. Pois esta ausência sinaliza também a impossibilidade de transformação. A poesia é sempre experiência da morte, é um atravessamento (pel)a morte - mas isso significa também que ela é um tecido, um casulo, da vida, o texto que transforma a vida, transfigura o mundo, muda suas figuras ("Do caleidoscópio / a vista ideal / mundo transfigurado / em dança / de cor em cor-desejo / no delírio do olho"), pela construção de uma Babel invertida, que não visa chegar ao céu, mas "exilar-se do céu" para viver neste mundo finito, um "exílio de ponta / cabeça", em que "nasce outro mapa / no céu por abismo / - - - / a pátria dos sonhos":

Por uma história da alegria

feito escada elevada

além do chão tão alta

até que alguém pensasse 
que todo o feito estava

apenas em chegar ao pé

dessa escada suspensa no ar

como se fôssemos somente

o sonho intranquilo

daquela borboleta 
232 Revista Texto Poético | ISSN: 1808-5385 | Vol. 16 (1ºm-2014) | p. 227-232 